\title{
EFFECTS OF GLOBALIZATION ON POVERTY AND GAP BETWEEN RICH AND POOR
}

\section{Tajana Toš Bublić}

Visoka škola za poslovanje i upravljanje „Baltazar Adam Krčelić“, Zaprešić, Hrvatska

\section{Nikolina Pavičić}

Visoka škola za poslovanje i upravljanje „Baltazar Adam Krčelić“, Zaprešić, Hrvatska

\section{Zlatko Rešetar}

Visoka škola za poslovanje i upravljanje „Baltazar Adam Krčelić“, Zaprešić, Hrvatska

\section{(C) MESTE NGO}

JEL Category: F02, 13, I32

\section{Apstrakt}

Nužan i neizbježan proces globalizacije nedvojbeno ima bezbroj pozitivnih učinaka, ali većini zemalja u razvoju globalizacija nije imala za posljedicu pozitivne gospodarske učinke. Najveći nedostatak tog procesa i najčešći argument skepticima $i$ kritičarima globalizacije $i$ njenih posljedica je sve veći jaz $u$ raspodijeli dohotka između bogatih i siromašnih.

To je i najčešća kritika prema MMF-u koji bi trebao igrati ulogu pomagača u sučeljavanju država sa izazovima globalizacije, ekonomskog razvoja, makroekonomske stabilnosti i smanjenju siromaštva.

Globalizacija je, danas s odmakom od "Washingtonskog konsenzusa“, shvaćena kao vrlo kontradiktorni proces. Sagledavanjem aktualnih istraživanja u ovom radu nepravedno su, ali namjerno izostavljeni pozitivni učinci i fokus je stavljen na literaturu koja prednost daje negativnim aspektima globalizacijskog procesa, u kontekstu rasta broj siromašnih i povećavanja jaza između siromašnih i bogatih.

Prvi dio rada teorijski sagledava neke od iznesenih kritika globalizacije s naglaskom na ulogu MMF-a i njegovim uspjesima i neuspjesima. U drugom dijelu rada je istražena povezanost između kretanja siromaštva i dohotka na svjetskoj razini, te raspodijeli povećanog dohotka, gdje su rezultati nedvojbeno na strani kritičara globalizacijskog procesa. Rezultati su u pojedinim slučajevima uspoređeni sa KOF indeksom globalizacije. Treći dio rada istraživanje sužuje na odabrane tranzicijske zemlje te u korelaciju dovodi kretanja GINI indeksa i KOF indeksa globalizacije, s osvrtom na navedena kretanja u Republici

Adresa autora zaduženog za korespodenciju:

Tajana Toš Bublić

埲= ttos@net.hr
Hrvatskoj.

Usporedbom dobivenih rezultata $s$ dosad objavljenim rezultatima rad zaključuje već puno puta spomenutu tezu o problematici strukture 
globalizacije i njenog temeljnog opredjeljenja za liberalizacijom tržišta, ako to za posljedicu ima još veću polarizaciju svijeta. Kao glavne krivce za negativne efekte globalizacije brojni autori pronalaze upravo u neadekvatnim institucionalnim mehanizmima, pa se kao moguće rješenje istraženih negativnih efekata pronalazi u regulatornim mehanizmima. I ponovno, kao i puno puta kroz povijesti, ekonomisti raspravljaju o ulozi države, ali u kontekstu globalne krize, neoliberalna ideja ima sve manje argumenata, a sve više siromaštva. Suvremenu ekonomiju danas je nemoguće zamisliti bez globalizacije. Ona je ta koja oblikuje ekonomska kretanja na svjetskoj razini. Krize se pretapaju iz razvijenih u nerazvijene zemlje. Suvremena ekonomija većini stanovništva donosi ekonomsku korisnost, ali prikazuje tendencije obrnute proporcionalnosti, budući da nanosi štetu najsiromašnijima.

Ključne riječi: globalizacija, siromaštvo, MMF

\section{Abstract}

Necessary and indivertible process of globalization undoubtedly has numerous positive effects, but for most of the developing countries globalization as a consequence didn't have positive economic effects. The most important disadvantage and the most often argument for the skeptics and critics of the globalization and its consequences is increasing gap in allocation of income between poor and rich. That is the most often critic towards IMF whose role should be helping governments to challenge globalization, economic development, macroeconomic stability and reduce poverty.

The globalization today, with time distance from "Washington consensus", is considered as deeply contradictory process. While analyzing recent studies in this paper unfairly, but on purpose the positive effects of globalization process are omitted and focus is on papers that are dealing with negative aspects in context of increasing number of poor and increasing gap between poor and rich.

The first part of the paper is considering some of the set out critics of globalization with a focus on role of the IMF and its accomplishment and failures. The second part of the paper is study of connection between movement of poverty and income, and distribution of the increased income, where the given results are undoubtedly on the side of the critics of globalization process. The results are in some cases compared with KOF index of globalization. The third part of the paper is narrowing study on the selected transitional countries and is examining the correlation between GINI index and KOF index of globalization, with review of given relations in Republic of Croatia.

Comparing results with up to now published results the paper is concluding a lots of time mentioned thesis about problems with globalization structure and its fundament regarding a liberalization of market, if all that for a consequence has a larger polarization of the world. The main culprit of globalizations negative effects large number of authors finds in inadequate institutional mechanisms, therefore the possible solution for negative effects is proposed in regulation mechanism. And again, as well as a many times throughout the history, neoliberal idea has less and less arguments and more and more poverty. It is impossible to imagine modern economy without globalization. Globalization is the one that shapes economic developments at the global level. The crisis spills over from developed to developing countries. A modern economy brings economic benefits to most of the population, but it also shows tendencies reverse proportionality, since it harms the poorest.

Key words: globalization, poverty, IMF

\section{UVOD}

Od informatizacije, liberalizacije, novih radnih mjesta, gospodarskog rasta, višeg životnog standarda, preko izlaska iz izoliranosti, prijenosa tehnologija i znanja, pa do dostupnosti lijekova, sporazuma o minama, strane pomoći siromašnim zemljama... Globalizacija ima gotovo neiscrpan popis pozitivnih posljedica na regije, zemlje i pojedince. Globalizacija se nikako ne može promatrati samo iz jednog kuta. To je ekonomskokulturno-političko-sociološki, pa i psihološki proces koji u svom djelovanju zahvaća gotovo sve aspekte življenja pojedinca, i gotovo svaki kutak svijeta. No, pozovemo li se na modelski pristup bez kojeg je gotovo nezamisliva današnja ekonomska znanost, globalizaciju možemo sagledati samo djelomično. Recimo da su pretpostavke našeg modela da su kulturološke i psihološke promjene jednake 0 , da globalizacija 
kao varijabla poput jednostave regresije djeluje samo na ekonomski aspekt. Djeluje li globalizacija pozitivno ili negativno i djeluje li na sve zemlje, regije i pojedince jednako?

Kada bi samo razvijene zemlje bile u modelu ekonomska intuicija i bez egzaktnih brojki govori nam da bi veza postojala, da bi ona bila pozitivna. No, kakav bi rezultat dao model za afričke zemlje ili zemlje Južne Amerike, za Indoneziju, Tajland ili Argentinu?

Gotovo je nemoguće pronaći rad o globalizaciji koji barem jednom u tekstu ne ističe da je globalizacija neizbježan proces. Ali radovi, kao i zaključci koje projiciraju su gotovo dijametralno suprotni. Dakle, globalizacija je, danas $s$ odmakom od "Washingtonskog konsenzusa", shvaćena kao vrlo kontradiktorni proces. Utjecaj globalizacije na rast BDP-a, BDP-a per capita, trgovinsku razmjenu, konkurentnost, razvijenost tehnologije, kvalitetu javnih institucija, kreditni rejting, cjenovni paritet samo su neki od naćina mjerenja ekonomskih učinaka globalizacije. Međutim, globalizacija se $u$ istraživanjima vrlo rijetko dovodi u odnos s jazom između bogatih i siromašnih i u odnos s brojem siromašnih.

Ovaj članak, stoga, sagledava ovisnost stupnja globalizacije i podatke o broju siromašnih, te jazu između bogatih i siromašnih dovodeći u korelaciju KOF indekse, GINI indekse, te broj siromašnih na svjetskoj razini, na razini odabranih zemalja, te za Hrvatsku u usporedbi sa drugim zemljama Europske unije. Očekivani rezultati istraživanja trebali bi i u ovoj korelaciji globalizacije i siromaštva, kao i u drugim radovima u kojima su analizirani drugačiji ekonomski učinci globalizacije, potvrditi kontraverznost globalizacijskog procesa.

Cilj istraživanja je dokazati nejednake posljedice globalizacijskog procesa sa aspekta siromaštva i jaza između bogatih i siromašnih i tako stvoriti temelj za dodatne rasprave $\mathrm{i}$ istraživanja utjecaja stupnja globalizacije, odnosno utvrditi neravnomjerno smanjenje u broju siromašnih na odabranim zemljama, te istražiti razliku u povećanju jaza između bogatih i siromašnih na odabranim zemljama sa osvrtom na Hrvatsku.

Istraživanjem će se pokušati odgovoriti na pitanja kako stupanj globalizacije utječe na broj siromašnih u pojedinim zemljama, te povećava li stupanj globalizacije jaz između bogatih i siromašnih.

\section{PRETHODNA ISTRAŽIVANJA}

\subsection{Kritika globalizacije}

Na 83. International Labour Conference održanoj 11. lipnja 1996. godine Jacques Chirac je rekao:

„Kako bi uspijeh od globalizacije bio na dobrobit svima (...) ekonomija mora biti takva da služi ljudima, a ne ljudi ekonomiji.

Svatko je obvezan da prizna, ipak, da taj proces globalizacije ima i svoje nedostatke, također. U industrionaliziranim narodima, to se nameće rapidno, a posljedično bolno restrukturiranje ima obrnute posljedice na situaciju sa zaposlenosti. $U$ najsiromašnijim zemljama, u međuvremenu, to može dovesti i do puno veće neravnomjernosti u raspodjeli. A to sve nameće rizik da određeni dijelovi svijeta polako postaju marginalizirani..."

(http://www.ilo.org/global/about-theilo/newsroom/news/WCMS_008059/lang-en/index.htm)

Uspijeh globalizacije kao nužnog i neizbježnog procesa sve više izaziva pažnju i skepticizam kako znanstvenog tako i političkog miljea. Globalizacija koja ima gotovo bezbroj pozitivnih efekata $i$ posljedica postaje sve kontraverznija. Što je izazvalo pojavu premise kontraverznosti i da li globalizacija u svom fundamentu nužnosti služi kao proces koji pridonosi općem dobru svih, a ne onih „bližih vatri“?

Skeptici i kritičari globalizacijskih procesa svoje argumente najčešće baziraju na siromaštvu prvenstveno gledano kroz raspodjelu dohodka i rasta jaza između bogatih i siromašnih do mjere neprihvatljivosti, a vjerovatno i neodrživost, te na stabilnosti u vidu financijskih kriza i velikih turbulencija na tržištima.

Joseph Stiglitz (2004) tako u djelu „Globalizacija i dvojbe koje izaziva" govori da je globalizacija krivac za krize i Aziji i Južnoj Americi, da nije ispunila očekivanja u Rusiji $i$ većini zemalja $u$ kojima je uvedeno tržišno gospodarstvo i zamijenilo komunistički sustav u smislu gospodarskog rasta, da je ukidanje trgovačkih zapreka naštetilo zapadnim zemljama, ali i npr. Amerikancima kao potrošačima. Selektivnost u ukidanju trgovačkih zapreka dovelo je, kako 
naglašava Stiglitz, u kombinaciji sa subvencijama do negativnog neto učinka (smanjenje cijena $u$ odnosu na uvoz) kod siromašnih zemalja, a u Južnoj Americi i Aziji, kao posljedica slabljenja nadzora nad tržištem ponovno su koristi imale Zapadne banke, dok su u tim zemljama ostavljane slomljene valute i oslabljeni bankarski sustavi.

„Kontrast između ruske pretvorbe, koju su isplanirale međunarodne gospodarske institucije, $i$ pretvorbe u Kini koju je ta zemlja sama osmislila, ne može biti veći. Dok je 1990. g kineski BDP iznosio $60 \%$ ruskog, do kraja desetljeća brojke su bile upravo suprotne. U Rusiji je neviđeno poraslo siromaštvo, a u Kini se broj siromašnih smanjio kao nikada prije.“ (Stiglitz, 2004, 26)

Sve veći jaz među bogatima i siromašnima ističu autori kao akumuliranje dobrih efekata globalizacije u već tradicionalno bogate zemlje, $u$ već ionako moćne multinacionalne kompanije, dok se ostatak svijeta bori s nametnutima promjenama od strane međunarodnih institucija i u većini postaje siromašniji, na rubu egzistencije.

Milanovic (2003) kritizira ideološke poglede na globalizaciju i daje pogled iz drugog kuta:

„Nešto je očito krivo“ (Milanovic, 2003, 679)

Postavlja pitanja kako objasniti da nakon velikih intervencija i strukturalnih pozajmica i uplitanja MMF-a afrički BDP per capita ostaje isti već 20 godina, štoviše u 24 afričke zemlje manji je nego 1975. godine ili kako je Argentina predstavljana kao pozitivan model reformi samo par mjeseci prije izbijanja krize. Milanovic traži objašnjenje i za tranzicijske zemlje poput Moldave ili Armenie koje su bez duga 1991. i prateći sve preporuke MMF-a deset godina nakon u situaciji kada trebaju oprost duga s BDP-om prepolovljanim.

„Tipična isprika da su politike dobre ali da su loše implementirane je kriva i zaista je vrlo jadna isprika."(Milanovic, 2003, 682)

Easterly u članku „Lost Decades“ dokazuje da su zemlje u razvoju stagnirale usprkos reformama od 1980-1998. te navodi:

"To je samo po sebi udarac optimističkom okruženju „Washingtonskog Koncenzusa“ (Esterly, 2001, 21)

Do istog je zaključka došao i Krugman (1995) kada govori da su ekonomska dostignuća zemalja koje su prihvatile Washingtonski koncenzus bila izrazito razočaravajuća.

\subsection{Kritika MMF-a}

Kritika globalizaciji i slobodnom tržištu usko je povezana sa kritikama upućenim Međunarodnom monetarnom fondu koji jednako kao i globalizacija nosi premisu kontraverznosti. Osnovan kao posljedica činjenice da tržišta mogu loše funkcionirati, danas zastupa ideju o dominaciji i prevlasti tržišta, osnovan na ideji da države trebaju povećati potrošnju, smanjiti poreze i kamatne stope, danas financijske injekcije dobivaju samo zemlje koje povećavaju porez i kamatne stope.

Neuspijesi MMF-a i „Washingtonskog koncenzusa" nizali su se iz godine u godinu. MMFova stroga monetarna politika najčešće je za posljedicu imala neotvaranja novih radnih mjesta preko visokih kamatnih stopa, Indonezija i Tajland nakon provođenja MMF-ovih smjernica imali su još veću krizu, ogromni neuspijeh je i Argentina, rast oboljelih od side na Tajlandu zbog smanjenja izdvajanja za zdravstvo, liberalizacija tržišta bez zakonske regulative i nestabilnost, privatizacija bez politike nadzora i tržišnog natjecanja. Neuspijeh se najčešće komentira u kontekstu zanemarivanja pojedinačne slike o zemlji, navikama, mentalitetu. MMF-ove politike su jednoobrazne, jedna politika za sve bez obzira na različitosti. Stiglitz stoga kaže: "Temeljna kritika pristupa kakav zastupa MMF ili „Washingtonski koncenzus" jest u tome što on ne prihavća da je za razvoj potrebna pretvorba društva" (Stiglitz, 2004, 96)

MMF tako izrazito lako nameće reforme jednostavnom ucjenom. Bez reformi nema financijske pomoći, no jesu li te reforme najbolje rješenje za određenu zemlju, u kojem je ona društvenom stupnju razvoja, može li se nositi sa tržišnim natjecanjem ili otvorenim bankarskim sustavom? Zašto u vodstvu MMF-a sjede samo razvijene velesile, zašto su sporazumi s MMF-om tajni i zašto MMF ne komentira svoje neuspijehe i ne revidira svoje politike usprkos njima?

„MMF s ponosom govori o napretku Južne Amerike $u$ tržišnim reformama posljednjeg desetljeća, no MMF ne spominje broj siromašnih“ (Stiglitz, 2004, 100) 
Toš Bublić T. Globalizacija i jaz između bogatih i siromašnih

FBIM Transactions Vol. 3 No. 1 pp. 108-120

\subsection{Posljedice siromaštvo \\ globalizacije} na

Globalizacija kao krovni pojam za ekonomsku liberalizaciju tržišta po definiciji bi trebala voditi k manjoj nezaposlenosti što bi onda trebalo smanjiti siromaštvo. Međutim, sve više znanstvenih radova preispituje ove intuicijske teze o liberalizaciji tržišta i dolazi do puno dubljih i preciznijih shvaćanja funkcioniranja tržišta. Le Goff i Singh (2013) prilikom istraživanja provedenog na 30 afričkih zemalja od 1981. do 2010. godine dokazuju da otvaranjem tržišta i njegovom liberalizacijom se uistinu može smanjiti siromaštvo ali samo ako je financijski sektor dovoljno razvijen, obrazovanje na visokoj razini i dovoljno snažna vlada države.

\section{METODOLOGIJA ISTRAŽIVANJA}

\subsection{Postavke istraživanja}

Istraživanjem se želi odgovoriti na dva postavljena pitanja:

I. Kako stupanj globalizacije utječe na broj siromašnih?

II. Kako stupanj globalizacije utječe na jaz između bogatih i siromašnih?

Da bi se pronašao odgovor na prvo postavljeno pitanje krenulo se od pretpostavke da se povećanjem stupnja globalizacije povećava $i$ stupanj razvijenosti. Mnogobrojni su kriteriji za mjerenje stupnja razvijenosti, a za potrebe ove analize stupanj razvijenosti analiziran je podacima o bruto nacionalnom dohodku po stanovniku (GNI per capita) konvertiran u US dolare po Atlas metodi Svjetske banke. Podaci se odnose na cijeli svijet odnosno na svjetski GNI per capita. Dobiveni podaci uspoređivani su sa kretanjem broja siromašnih odnosno postotka svjetske populacije koja živi s manje od $2 \$$ dnevno, a dobiveni rezultati pokazat će odnose stupnja razvijenosti i postotka siromaštva na svjetskoj razini. Kako bi provjerili intuicijsku tezu da globalizacija smanjuje broj siromašnih analizirat će se KOF indeks globalizacije i postotak siromašnih za Argentinu i Kinu, prilikom čega se nastojalo uzeti zemlje drugačijih geografskih, političkih i gospodarskih karakteristika.

Nekoliko je indikatora heterogenosti u distribuciji dohodka, a među njima najčešće korišten GINI indeks. lako GINI indeks ne daje potpunu sliku distribucije dohodka jer, kako je dokazao Gabriel Palma, pokazuje distribuciju dohodka u „4 sloja“,ali pokazuje što se dogđa samo u pola svijeta $i$ to na samom vrhu i dnu distribucije (Palma, 2003), analiza za dobivanje odgovora na drugo postavljeno pitanje bazirana je na GINI indeksu i KOF indeksu globalizacije. Podaci su uspoređeni za Argentinu i Kinu kao nastavak prethodne analize, te za tranzicijske zemlje Hrvatsku, Slovačku, Mađarsku i Rusiju.

Tablica 1: Vremenski period i izvori podataka

\begin{tabular}{|c|c|c|c|}
\hline & Vrsta podataka & Vremenski period & Izvor \\
\hline \multirow[t]{2}{*}{ SVIJET } & GNI per capita & $1981-2010$ & World Bank \\
\hline & $\%$ ljudi koji živi s manje od $2 \$$ dnevno & $1981-2010$ & World Bank $^{* * *}$ \\
\hline \multirow[t]{2}{*}{ Argentina } & $\%$ ljudi koji živi s manje od $2 \$$ dnevno & $1991-2010$ & World Bank ${ }^{* * *}$ \\
\hline & KOF indeks & $1991-2010$ & ETH Zurich* \\
\hline \multirow[t]{2}{*}{ Kina } & \% ljudi koji živi s manje od $2 \$$ dnevno & 1981-2008 (svake tri godine) & World Bank $^{* * *}$ \\
\hline & KOF indeks & 1981-2008 (svake tri godine) & ETH Zurich \\
\hline \multirow[t]{2}{*}{ Hrvatska } & GINI indeks & $1998-2008$ & World bank** \\
\hline & KOF indeks & 1998-2008 & ETH Zurich \\
\hline \multirow[t]{2}{*}{ Slovačka } & GINI indeks & 1996-2009 & World Bank $^{* *}$ \\
\hline & KOF indeks & 1996-2009 & ETH Zurich \\
\hline \multirow[t]{2}{*}{ Mađarska } & GINI indeks & $1987-2007$ & World Bank ${ }^{* *}$ \\
\hline & KOF indeks & $1987-2007$ & ETH Zurich \\
\hline \multirow[t]{2}{*}{ Rusija } & GINI indeks & 1993-2009 & World Bank $^{* *}$ \\
\hline & KOF indeks & $1993-2009$ & ETH Zurich \\
\hline
\end{tabular}

*http://globalization.kof.ethz.ch/

**http://data.worldbank.org/indicator/SI.POV.GINI

***http://data.worldbank.org/indicator/SI.POV.2DAY 


\subsection{Model i obrada podataka}

Kretanje broja siromašnih promatrat čemo na temelju podataka za ljude koji žive s manje od 2 američka dolara na dan, a prema podacima World Bank u periodu od 1981. do 2010. godine (v. Tablica 1). Broj siromašnih uspoređen je sa kretanjem GNI per capita(Athlas method). Podaci su grafički obrađeni i uspoređeni.

Odnos utjecaja stupnja globalizacije na broj siromašnih tj. utjecaj jedne varijable na drugu analizirat će se jednostavnom linearnom regresijom. Analizom se provjerava korelacijska veza između stupnja globalizacije služeći se KOF indeksom kao nezavisnom varijablom i broja ljudi koji žive s manje od dva dolara dnevno kao zavisnom varijablom u modelu.

Regresijska jednadžba glasi:

$y_{i}=\alpha+\beta x_{i}+\varepsilon_{i}, \quad i=1,2 \ldots, n$

gdje su $\alpha$ i $ß$ nepoznati parametri, a varijabla $\varepsilon$ je greška u modelu. Model sa procijenjenim paramerima glasi:

$\hat{y}=\hat{\alpha}+\hat{\beta} x$.

Regresijske vrijednosti izračunate su koristeći izraz

$\hat{y}=\hat{\alpha}+\hat{\beta} x_{i}, \quad i=1,2 \ldots, n$.

Regresijska vrijednost je procjena zavisne varijeble $Y$ sa stvarnom vrijednošću nezavisne varijable $X$, a razlika između regresijske vrijednosti i stvarne vrijednosti zavisne varijable je greška $\widehat{\varepsilon}$. .

Odnos utjecaja stupnja globalizacije na heterogenost distribucije dohodka, tj. utjecaj KOF indeksa globalizacije i GINI indeks također je analizirano jednostavnom linearnom regresijom gdje je KOF indeks globalizacije nezavisna varijabla, a GINI indeks zavisna varijabla u modelu. Korištena je ista regresijska jednadžba kao i kod predhodnog modela. Podaci su analizirani za Agrentinu i Kinu, kao nastavak predhodne analize, te za Hrvatsku, Slovačku, Mađarsku i Rusiju.

Napominjemo da podaci za zemlje nisu međusobno usporedivi jer su promatrana vremenska razdoblja drugačija kao posljedica šturijih podataka vezanih za KOF indeks i GINI indeks zemalja.

\section{REZULTATI ISTRAŽIVANJA}

\subsection{Analiza broja siromašnih s obzirom na GNI per capita}

Kretanje broja siromašnih praćen je na temelju podataka za ljude koji žive s manje od 2 američka dolara na dan za period od 1981 od 2010 godine, a prema podacima World Bank daju se i podaci podjeljeni u 6 svjetskih regija.

Tablica 2: \% ljudi koji žive s manje od 2\$ dnevno s obzirom na ukupno stanovništvo regije

\begin{tabular}{|l|c|c|c|c|c|c|c|c|c|c|c|}
\hline & 1981 & 1984 & 1987 & 1990 & 1993 & 1996 & 1999 & 2002 & 2005 & 2008 & 2010 \\
\hline $\begin{array}{l}\text { Istočna Azija i } \\
\text { Pacifik }\end{array}$ & 92,15 & 87,81 & 80,96 & 80,44 & 75,2 & 63,24 & 60,99 & 51,24 & 38,29 & 32,59 & 29,14 \\
\hline $\begin{array}{l}\text { Europa i } \\
\text { Centralna Azija }\end{array}$ & 8 & 6,42 & 6,07 & 6,54 & 9,32 & 11,16 & 11,87 & 7,65 & 4,43 & 2,12 & 2,27 \\
\hline $\begin{array}{l}\text { Latinska } \\
\text { Amerika }\end{array}$ & 23,37 & 26,44 & 21,97 & 21,99 & 21,3 & 20,68 & 21,65 & 21,61 & 16,35 & 12,09 & 10,18 \\
\hline $\begin{array}{l}\text { Srednji Istok i } \\
\text { Sjeverna Afrika }\end{array}$ & 29,32 & 26,42 & 25,43 & 22,77 & 21,41 & 21,49 & 21,25 & 19,05 & 16,73 & 13,34 & 11,55 \\
\hline Južna Azija & 86,74 & 85,03 & 83,93 & 83,02 & 82,05 & 80,05 & 77,12 & 76,68 & 72,57 & 70,05 & 65,8 \\
\hline $\begin{array}{l}\text { Sub-Saharska } \\
\text { Afrika }\end{array}$ & 71,69 & 74,23 & 73,81 & 75,49 & 77,68 & 77,08 & 77,04 & 75,63 & 73,54 & 70,28 & 69,31 \\
\hline Ukupno & 69,21 & 67,51 & 64,23 & 64,1 & 65,57 & 58 & 56,83 & 52,83 & 46,25 & 42,65 & 40,08 \\
\hline
\end{tabular}

Izvor: Izradili autori prema podacima World Bank

Tablica 3: Broj ljudi koji žive s manje od 2\$ dnevno u svijetu (u milijunima)

\begin{tabular}{|l|r|r|r|r|r|r|r|r|r|r|r|}
\hline & 1981 & 1984 & 1987 & 1990 & 1993 & 1996 & 1999 & 2002 & 2005 & 2008 & 2010 \\
\hline Ukupno & 2571,27 & 2662 & 2688 & 2842 & 2919 & 2837 & 2907 & 2815 & 2561 & 2450 & 2360 \\
\hline
\end{tabular}


Toš Bublić T. Globalizacija i jaz između bogatih i siromašnih

FBIM Transactions Vol. 3 No. 1 pp. 108-120

Analizirajući podatke o broju siromašnih $u$ postotku ukupnog stanovništva vidljivo je da siromaštvo ima tednedciju smanjenja. Tako od gotovo $70 \%$ 1981. godine do 2010. godine postotak ljudi koji žive sa manje od $2 \$$ dnevno se smanjio na 40,08\%. Podaci djeluju obečavajuće.
Naravno, podaci su izrazito dobri za Istočnu Aziju i Pacifik koji u bitnome poboljšavaju sliku o svjetskom siromaštvu, no podaci za Afriku su i dalje poražavajući. U tri desetljeća postotak najsiromašnijih u Africi smanjio se samo za neprimjetnih $2 \%$.

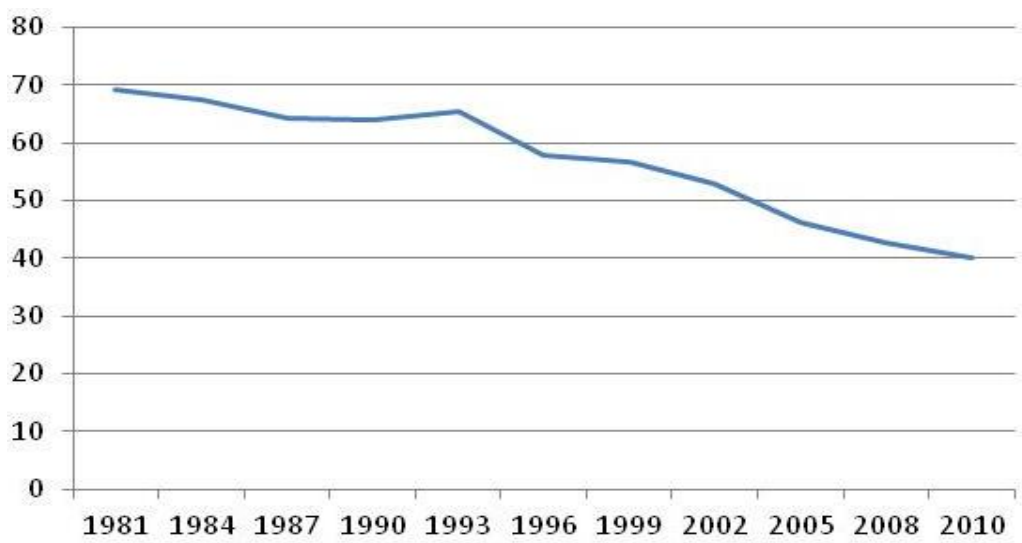

Grafikon 1. \% ljudi koji žive s manje od $2 \$$ dnevno s obzirom na ukupnan broj stanovnika na svijetu Izvor: Izradili autori prema podacima World Bank

Tablica 4: Svjetski GNI per capita Athlas metoda (u tekućim US\$)

\begin{tabular}{|ll|}
\hline GODINA & GNI/C \\
\hline 1981 & $2,653.1$ \\
\hline 1982 & $2,517.0$ \\
\hline 1983 & $2,386.1$ \\
\hline 1984 & $2,432.2$ \\
\hline 1985 & $2,510.1$ \\
\hline 1986 & $2,766.4$ \\
\hline 1987 & $3,222.4$ \\
\hline 1988 & $3,809.0$ \\
\hline 1989 & $3,962.2$ \\
\hline 1990 & $4,094.8$ \\
\hline
\end{tabular}

\begin{tabular}{|ll|}
\hline GODINA & GNI/C \\
\hline 1991 & $4,220.9$ \\
\hline 1992 & $4,523.2$ \\
\hline 1993 & $4,607.2$ \\
\hline 1994 & $4,798.0$ \\
\hline 1995 & $5,083.7$ \\
\hline 1996 & $5,319.2$ \\
\hline 1997 & $5,361.1$ \\
\hline 1998 & $5,117.7$ \\
\hline 1999 & $5,123.3$ \\
\hline 2000 & $5,296.3$ \\
\hline
\end{tabular}

\begin{tabular}{|ll|}
\hline GODINA & GNI/C \\
\hline 2001 & $5,264.5$ \\
\hline 2002 & $5,221.3$ \\
\hline 2003 & $5,620.2$ \\
\hline 2004 & $6,420.5$ \\
\hline 2005 & $7,122.0$ \\
\hline 2006 & $7,598.0$ \\
\hline 2007 & $8,103.5$ \\
\hline 2008 & $8,700.4$ \\
\hline 2009 & $8,695.2$ \\
\hline 2010 & $9,090.2$ \\
\hline
\end{tabular}

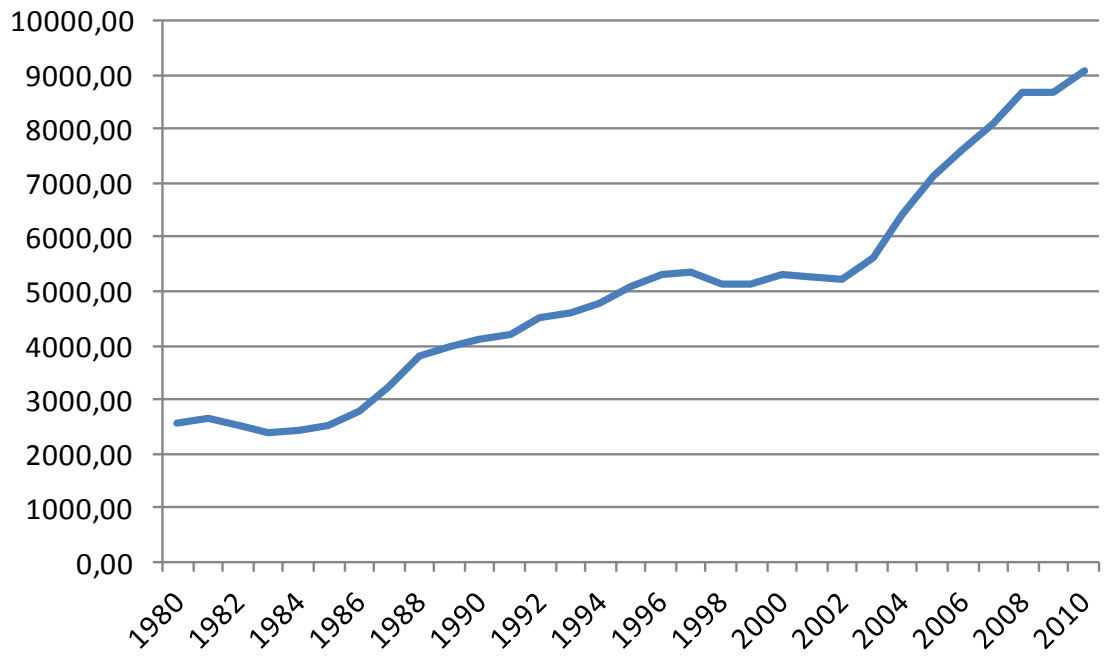

Grafikon 2. Svjetski GNI per capita Athlas metoda (u tekućim US\$) Izvor. Izradili autori prema podacima World Bank 
Prema podacima World Bank bruto domaći dohodak u US dolarima prema Athlas metodi bilježi rast posebice u periodu od 2002. godine do 2010. godine što je vidljivo iz grafikona 2 .

Prvi trend koji uočavamo je da je svjetski razvoj pratilo i smanjenje broja siromašnih, ali je trend rasta svjetskog razvoja bitno brži od trenda smanjenja siromaštva. Smanjenje siromaštva u apsolutnom broju od 2571,27 milijuna ljudi u 1981. godini do 2360 milijuna ljudi u 2010. godini iznosi tek $8,2 \%$. Smanjenje siromaštva $s$ obzirom na ukupan broj stanovnika za promatrano razdoblje od 1981. do 2010 . za $29,13 \%$ očito ne prati trend u povećanju GNI per capita koji se za promatrani period povećao za čak $243 \%$. Zaključak koji slijedi, jedini moguć iz iznesenih podataka, jest da su ovi nesrazmjeri morali dovesti do većeg jaza između bogatih i siromašnih.

\subsection{Analiza broja siromašnih $s$ obzirom na stupanj globalizacije}

Odnos utjecaja stupnja globalizacije na broj siromašnih analiziran je na podacima za Agrentinu i Kinu. Navedene zemlje su odabrane nasumično, prilikom čega se nastojalo uzeti zemlje drugačijih geografskih, političkih i gospodarskih karakteristika.

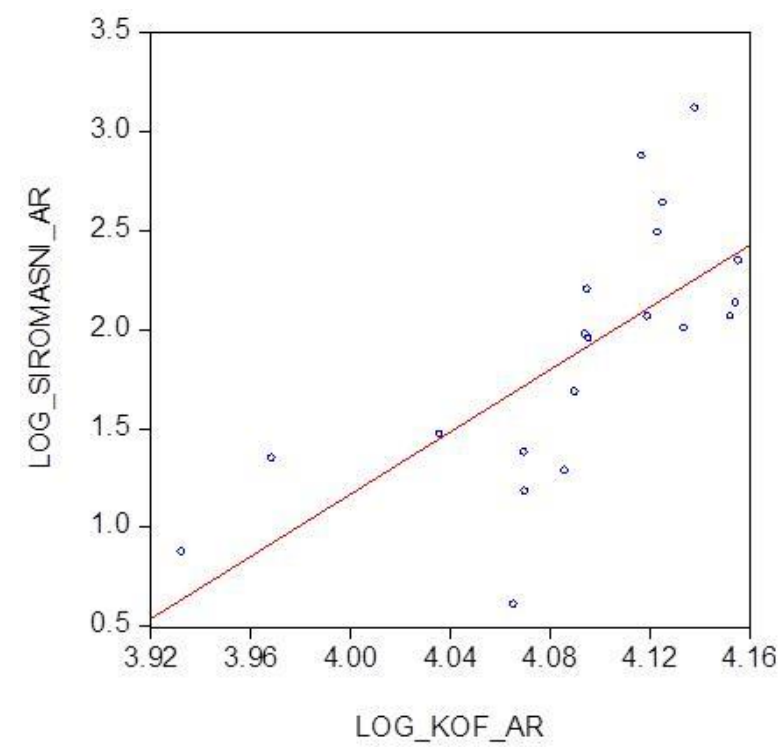

Grafikon 3: Dijagram rasipanja logaritam postotka ljudi koji žive s manje od $2 \$$ dnevno i logaritam KOF indeksa globalizacije (Argentina)

Izvor: Izradili autori

$\mathrm{U}$ analizi je korišten log-log model tako da su korištene varijable modela bile:
LOG_SIROMASNI_AR $=\log$ (broj ljudi u Argentini koji žive s manje od $2 \$$ dnevno)

LOG_KOF_AR $=\log ($ KOF indeks za Argentinu $)$

LOG_SIROMASNI_CH $=\log$ (broj ljudi u Kini koji žive s manje od $2 \$$ dnevno)

LOG_KOF_CH $=\log (\mathrm{KOF}$ indeks za Kinu)

Prema podacima od 1991. do 2010. godine iz dijagrama rasipanja jasno se vidi da globalizacija u Argentini nije za posljedicu imala očekivani rezultat.

Neočekivani rezultati svakako su argument kritičarima globalizacije jer bi na ovom pojedinačnom slučaju sva ekonomska teorija o globalizaciji, otvaranju tržišta i smanjenju siromašta morala biti po definiciji samo ideologija koja u stvarnosti kao i puno puta u povijesti ideologija ne projicira očekivane rezultate. Argentinski model jasno i nedvojbeno pokazuje da rastom stupnja globalizacije raste i broj siromašnih ljudi. Za točnije podatke koristit ćemo jednostavnu linearnu regresiju s log - log modelom. Jednadžba regresije $s$ procjenjenim parametrima glasi:

LOG_SIROMASNI_AR $=-30,2676288918+$ 7,85903234518LOG_KOF_AR

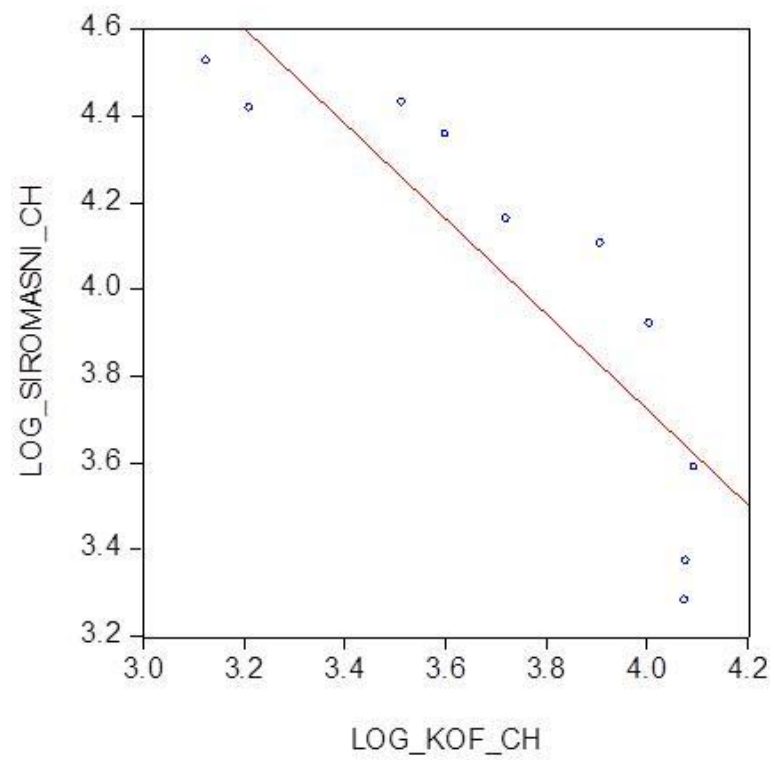

Grafikon 4: Dijagram rasipanja logaritam postotka ljudi koji žive s manje od $2 \$$ dnevno i logaritam KOF indeksa globalizacije (Kina)

Izvor: Izradili autori

Interpretacija rezultata linearne regresije je: Ako se kof indeks globalizacije poveća za $1 \%$ postotak ljudi koji žive s manje od $2 \$$ dnevno će se u 
prosjeku povećati za $7,85 \%$. Na razini značajnosti $5 \%$, p-vrijednost varijable je manja od $\alpha$ što znači da je varijabla značajna $u$ modelu. $R^{2} u$ ovom modelu iznosi 0,489432 što znači da je ovim modelom protumačeno $48,94 \%$ svih odstupanja.

Obrađeni podaci za Kinu odnose se na period od 1981. godine do 2008. godine i to svake tri godine. Prema dijagramu rasipanja potvrđuju teorijsko shvaćanje globalizacije, upravo suprotno od argentinskog modela.

Dijagram jasno pokazuje da se povećanjem stupnja globalizacije smanjio postotak ljudi koji žive s manje od $2 \$$ dnevno. Rezultat je očekivan jer Azija na čelu sa Kinom je svakako udžbenički primjer kako otvaranje tržišta generira radna mjesta, a time i posljedično smanjuje stopu siromaštva. Za točnije podatke provedena je jednostavna linearna regresija korištenjem log log modela. Jednadžba regresije s procjenjenim parametrima glasi:

\section{LOG_SIROMASNICH $=8,12025868165-$ 1,09917466854LOG_KOF_CH}

Interpretacija rezultata linearne regresije je: Ako se kof indeks globalizacije poveća za $1 \%$ postotak ljudi koji žive s manje od $2 \$$ dnevno će se u prosjeku smanjiti za 1,099\%. Na razini značajnosti $5 \%$, p-vrijednost varijable je manja od $\alpha$ što znači da je varijabla značajna u modelu. $R^{2}$ u ovom modelu iznosi 0,755553 što znači da je ovim modelom protumačeno $75,55 \%$ svih odstupanja.

Ova dva kontradiktorna primjera o korelaciji stupnja globalizacije i siromaštva još su jedan od brojnih primjera kontraverznosti globalizacijskog procesa. Svakako da bi za svaku od analiziranih zemalja mogli navesti još brojne čimbenike, varijable i okolnosti koje su utjecale na baš ovakvo kretanje stope siromaštva, ali za potrebe ovog rada zaustavit ćemo se na indeksu globalizacije.

\subsection{Aanliza stupnja globalizacije i jaza između bogatih i siromašnih}

Za analizu odabrane su dvije već analizirane zemlje, dakle Kina i Argentina, ali i tranzicijske zemlje Hrvatska, Slovačka, Mađarska, te Rusija.

Analizirana je povezanost GINI indeksa i KOF indeksa globalizacije.

Jednadžbe regresije s procjenjenim parametrima glase:
Kina

LOG GINI C = 2,04709074785 + $0,417080565908^{*}$ LOG_KOF_C

Argentina LOG_GINI $=1,38390670741+$ $0,611653758656 *$ LOG KOF

Hrvatska LOG_GINI_H $=1,24459666478+$ $0,5154834 \overline{8} 4222 *$ LOG_KOF_H

Slovačka LOG_GINI_S $=2,15820385474+$ $0,264725253664 *$ LOG_KOF_S

Mađarska LOG_GINI_M $=1,37283875572+$ 0,4457718071*LOG_KOF_M

Rusija

LOG_GINI_R = 5,91171094961 0,535069947463*LOG_KOF_R

Rezultati svih modela na razini zančajnosti od $5 \%$ imaju $p$-vrijednost varijable manju od $\alpha$, dakle varijabla je značajna u modelu osim model sa Slovačkom gdje $p$-vrijednost iznosi više od $\alpha$.

Rezultati prema interpretaciji za sve navedene zemlje osim Rusiju glase ako se KOF indeks globalizacije poveća za $1 \%$ GINI indeks će se u prosjeku povećati za $ß$ vrijednosti iz jednadžbi. Interpretacija za Rusiju glasi upravo suprotno, tj. da će se GINI indeks u prosjeku smanjiti, a što je vidljivo i iz dijagrama rasipanja. Rusija je jedini primjer od ovdje analiziranih zemalja koja se uslijed većeg stupnja globalizacije može pohvaliti i sa nižim GINI indeksom.

Rezultati potkrepljuju pretpostavke na temelju podataka dobivnih iz prvog dijela rada 0 siromaštvu i GNI per capita koji se kreću u nesrazmjeru. Uslijed većeg stupnja globalizacije zemlje raste i nesrazmjer između bogatih i siromašnih. Naravno, dobiveni podaci ovdje su generalizirani, ali svakako ne govore u prilog globalizacijskom procesu.

Lako je vidljivo upravo kontraverzno obilježje na primjeru Kine, koja je često isticana kao pozitivan primjer globalizacijskog procesa. Uslijed smanjenja siromaštva Kina može očekivati i povećanje nejednakosti među stanovništvom.

Međutim, ovakva generalizacija u kojoj se pretpostavlja da je globalizacija okidač za povećanje dohodovne nejednakosti trebala bi u model uzeti puno više varijabli koje su mogle, osim globalizacije, utjecati na nejednakost. Tako je primjerice pomoću panel analize 16 OECD zemalja pokušano dokazati što utječe na nejednakosti i rezultati su jasno pokazali da na distribuciju dohodka utječe puno faktora od kojih su neki općeniti za sve, a neki specifični za pojedinu zemlju. (Gustafsson i Johansson, 1997) 

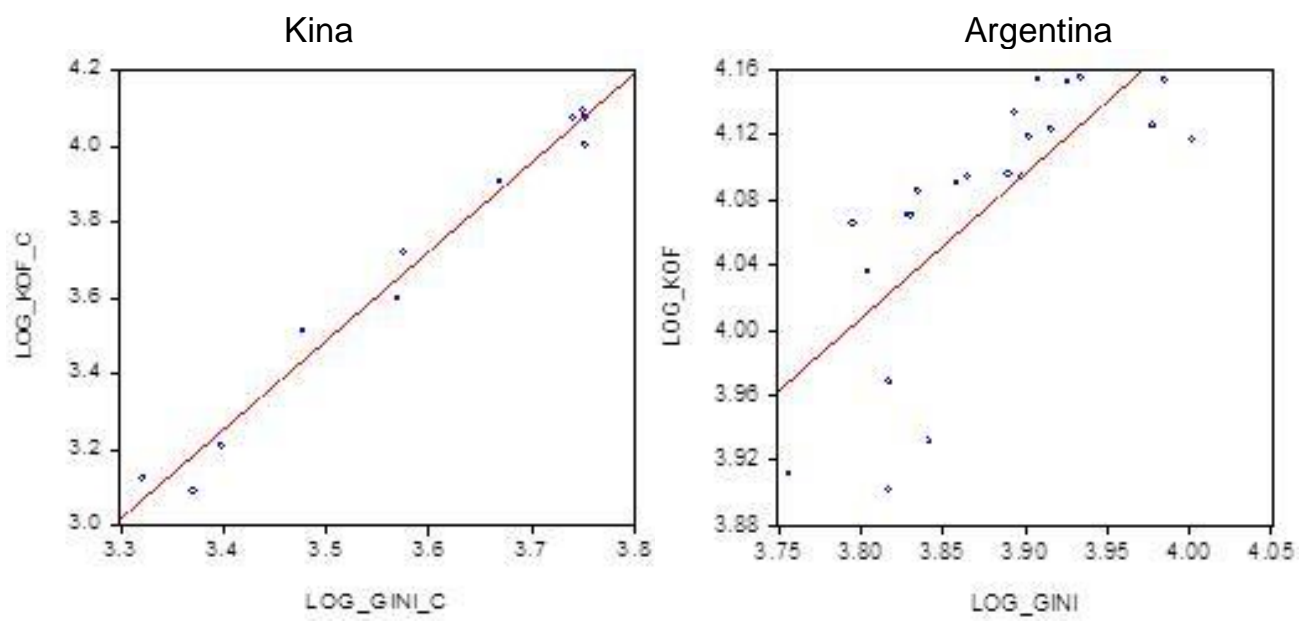

Hrvatska
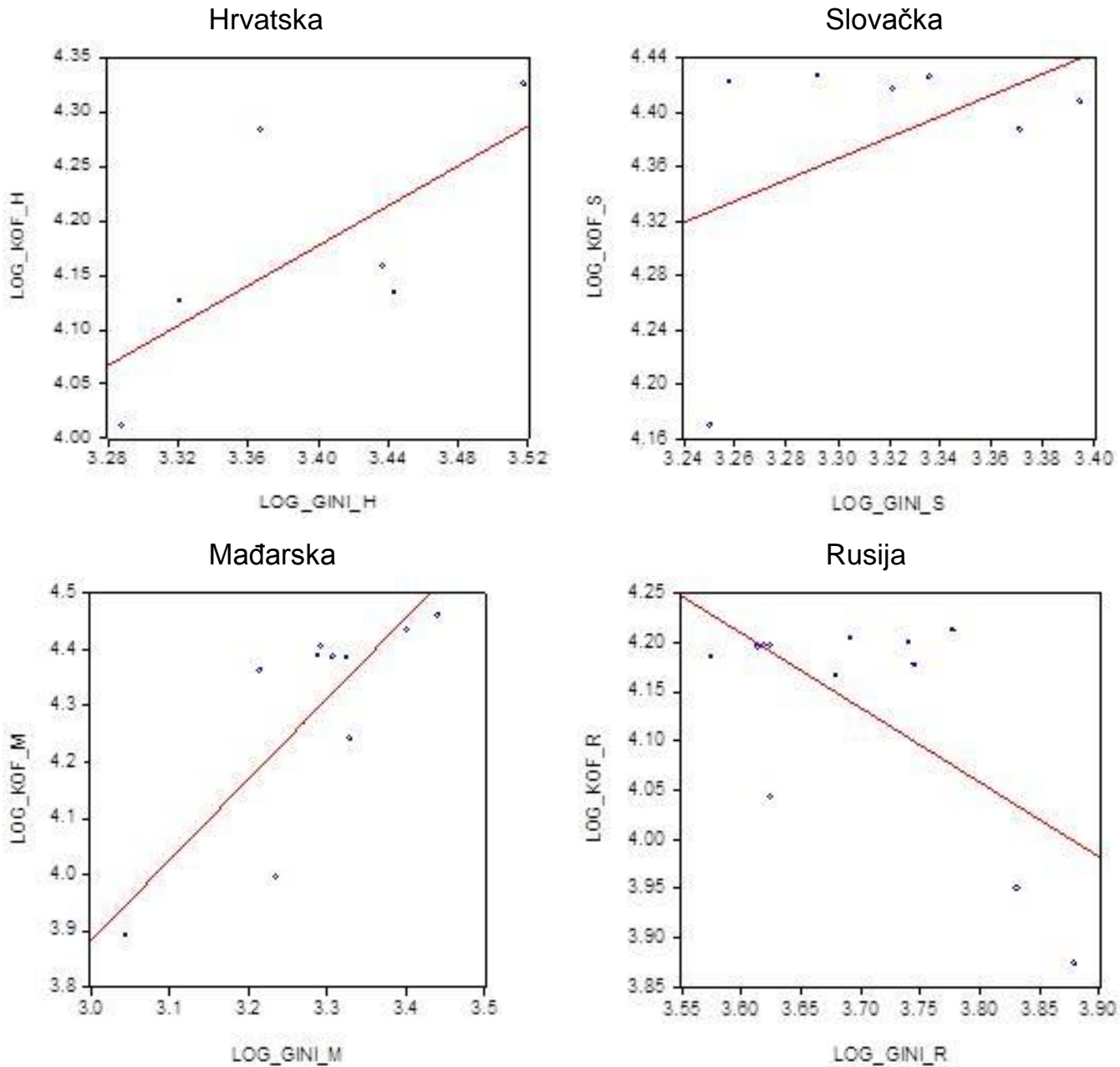

Grafikon 5: Dijagrami rasipanja logaritam GINI indeksa i logaritam KOF indeksa globalizacije

Izvor: Izradili autori

\subsection{Osvrt na Hrvatsku}

Hrvatska se prema ukupnim podacima za tranzicijske zemlje nalazi otprilike na sredini po uspješnosti tranzicijskih procesa, a time naravno i procesa globalizacije. Analizirajući podatke o ljudima koji žive $s$ manje od $2 \$$ na dan zaključujemo da je Hrvatska pozicija u svijetu na zavidnom mjestu.

Međutim, iako su podaci za Hrvatsku šturi i nedovoljni za dublju analizu ako pratimo kretanje KOF indeksa globalizacije i GINI indeksa onda zaključujemo da se jaz između bogatih i siromašnih povećava. 
Toš Bublić T. Globalizacija i jaz između bogatih i siromašnih

FBIM Transactions Vol. 3 No. 1 pp. 108-120

Tablica 5. Kof, Gini indeks i postotak ljudi koji žive s manje od 2\$ dnevno u Hrvatskoj

\begin{tabular}{|l|r|r|r|r|r|r|}
\cline { 2 - 7 } \multicolumn{1}{c|}{} & 1998 & 1999 & 2000 & 2001 & 2004 & 2008 \\
\hline Kof & 55,25 & 61,89 & 62,44 & 63,96 & 72,51 & 75,6 \\
\hline Gini & 26,82 & 27,71 & 31,33 & 31,1 & 28,99 & 33,65 \\
\hline$\%<2 \$$ dnevno & 0,1 & 0,32 & 0,14 & 0,14 & 0,08 & 0,09 \\
\hline
\end{tabular}

Izvor: Izradili autori prema podacima World Bank

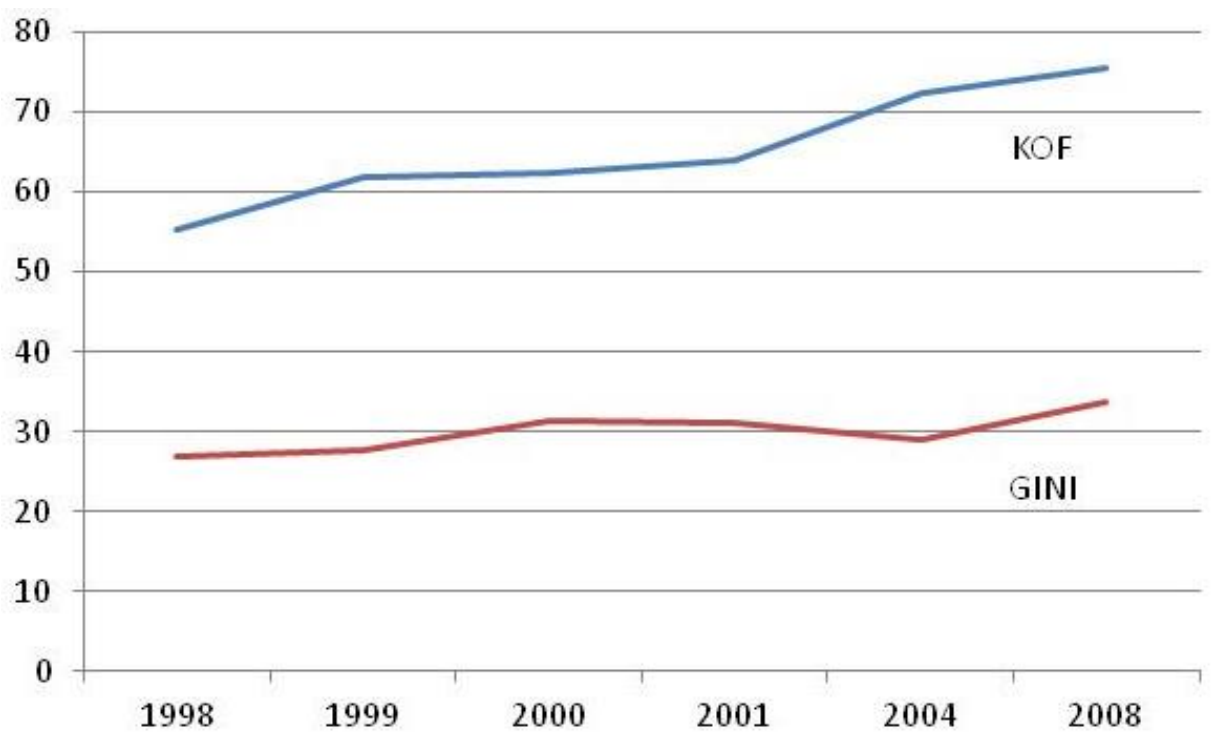

Grafikon 6. Kof i Gini indeks za Hrvatsku

Izvor: Izradili autori

Upravo podaci za Hrvatsku pokazuju i trend Europske Unije. lako za EU, kao razvijenu regiju svijeta, podaci o siromaštvu ljudi koji žive sa $2 \$$ dnevno i nisu relevantni kao što su za siromašne zemlje poput nekih afričkih, zabrinjavajući su podaci koje je objavio Eurostat, a odnose se na 2012.

godinu.

(http://epp.eurostat.ec.europa.eu/statistics_explai ned/index.php) Prema iznesenim podacima Eurostata, u 2012. godini 124,5 milijuna ljudi ili $24,8 \%$ populacije EU-28 nalaze se na rubu siromaštva (prema AROPE) u usporedbi sa $24,3 \%$ iz 2011. godine. AROPE pokazatelj, izračunat kao prosjek nacionalnih rezultata, pokazuje značajne rezlike među članicama. Tako su zemlje članice sa najvećom AROPE stopom Bugarska (49,3\%) i Rumunjska (41,7\%), dok su zemlje s najmanjim udiom populacije koja ima rizik od siromaštva Nizozemska (15\%), Češka (15,4\%) i Finska $(17,2 \%)$. Podaci za Hrvatsku i Mađarsku su podjednaki i iznose $32 \%$ stanovništva koje ima rizikom od siromaštva.

Ulaskom Hrvatske u EU, prema provedenim analizama, zaključujemo da se podaci za broj siromašnih ljudi koji žive s manje od $2 \$$ dnevno ne bi se trebao povećavati niti bitno mijenjati, ali možemo očekivati daljnji rast jaza između bogatih i siromašnih, i to brže nego u promatranom razdoblju ako će Hrvatska pratiti trendove ostalih zemalja članica. Dobiveni podaci i pretpostavke u skladu su sa podacima predstavljenim od strane Eurostata koji projiciraju vjerovatno povećanje broja ljudi kojima prijeti siromaštvo ili se nalaze na rubu siromaštva.

\section{ZAKLJUČAK}

Pretpostavka globalizacije je da, uz sve ostale pozitivne posljedice, utječe i na smanjenje broja siromašnih i smanjenje jaza između bogatih i siromašnih. Usporedbom dobivenih rezultata $s$ dosad objavljenim rezultatima možemo zaključiti već puno puta spomenutu tezu o problematici strukture globalizacije i njenog temeljnog opredjeljenja za liberalizacijom tržišta. Neosporna je činjenica da se broj siromašnih smanjuje iz godinu u godinu, no da li se to može pripisati globalizacijskom procesu uz sve neuspijehe koje je doživio u pojedinim država ili je to naprosto tijek kojim bi broj siromašnih ionako išao, teško je dokazati. Međutim nesporna je činjenica da 
dohodak raste $u$ nesrazmjeru sa smanjivanjem broja siromašnih. „Nejednakosti su dostigle neslućene razmjere" (Jovančević, 2005, 19) Je li to samo stvar inertnosti u preljevanju globalizacijskih pozitivnih pomaka na one najsiromašnije ili je globalizacija ideologija na papiru koja ima drugačije posljedice u stvarnosti. Analizom broja siromašnih i bruto nacionalnog dohotka zaključak zasigurno pomalo i ljuti zagovornike globalizacije. Rezultati nisu obečavajući niti analizom jaza između bogatih i siromašnih. Taj jaz ne samo da se ne smanjuje već se u većini analiziranih zemalja povećava. Najčešći argument za ovakve rezultate je da su liberalizacije tržišta loše integrirane u postojeće državne gospodarske, političke i kulturne karakteristike. Kao glavne krivce za negativne efekte globalizacije brojni autori pronalaze upravo $\mathrm{u}$ neadekvatnim institucionalnim mehanizmima, pa se kao moguće rješenje istraženih negativnih efekata pronalazi u regulatornim mehanizmima.

\section{Citirani radovi}

Easterly, W. (2001). The Lost Decades: Developing Countries Stagnation in Spite of Policy Reform 1980-1988. Journal of Economic Growth. 6(22). 135-157.

Gustafsson, B. i Johansson, M. (1997) In Search for a Smoking Gun: What Makes Income Inequality Vary Over Time in Different Countries?. Luxemburg Incom Studies Working Paper Series. 172. 1-58.

Jovančević, R. (2005). Ekonomski učinci globalizacije i Europska unija. Zagreb: Merkon promet.

Krugman, P. (1995). Dutch tulips and Emerging Markets, Foreign affairs, New York, NY : Council on Foreign Relations. 74. 28-44.

Le Goff,M. i Singh, R. J. (2013) Does Trade Reduce Poverty: A view from Africa. World Bank working paper. Vol. 6327. 1-25

Milanovic, B. (2003). The Two Faces of Globalization: Against Globalisation as we know it. World Development. 31(4). 676-683.

Palma, G. (2003) National inequality in the era of globalisaton: what do recent data tell us?, The Handbook of Globalisation. 104-135.

Stiglitz, J. (2004). Globalizacija i dvojbe koje izaziva. Zagreb: Algoritm

Datum prve prijave:

Datum prijema korigovanog članka:

Datum prihvatanja članka:
28.03.2014

30.12 .2014

05.01 .2015

\section{Kako citirati ovaj rad? / How to cite this article?}

\section{Style - APA Sixth Edition:}

Toš Bublić, T., Pavičić, N., \& Rešetar, Z. (2015, Jan 15). Posljedice globalizacije na siromaštvo i jaz između bogatih i siromašnih. (Z. Čekerevac, Ed.) FBIM Transactions, 3(1), 108-120. doi:10.12709/fbim.03.03.01.13

\section{Style - Chicago Sixteenth Edition:}

Toš Bublić, Tatjana, Nikolina Pavičić, and Zlatko Rešetar. 2015. "Posljedice globalizacije na siromaštvo i jaz između bogatih i siromašnih." Edited by Zoran Čekerevac. FBIM Transactions (MESTE) 3 (1): 108-120. doi:10.12709/fbim.03.03.01.13. 


\section{Style - GOST Name Sort:}

Toš Bublić Tatjana, Pavičić Nikolina and Rešetar Zlatko Posljedice globalizacije na siromaštvo i jaz između bogatih i siromašnih [Journal] // FBIM Transactions / ed. Čekerevac Zoran. - Beograd : MESTE, Jan 15, 2015. - 1 : Vol. 3. - pp. 108-120.

Style - Harvard Anglia:

Toš Bublić, T., Pavičić, N. \& Rešetar, Z., 2015. Posljedice globalizacije na siromaštvo i jaz između bogatih i siromašnih. FBIM Transactions, 15 Jan, 3(1), pp. 108-120.

Style - ISO 690 Numerical Reference:

Posljedice globalizacije na siromaštvo i jaz između bogatih i siromašnih. Toš Bublić, Tatjana, Pavičić, Nikolina and Rešetar, Zlatko. 2015. [ed.] Zoran Čekerevac. 1, Beograd : MESTE, Jan 15, 2015, FBIM Transactions, Vol. 3, pp. 108-120. 